\title{
Cover plants as a suppression and increasing tool to hairy fleabane control
}

\author{
André Guareschi ${ }^{1} \oplus$, Joanei Cechin ${ }^{1} \oplus$, Mário Antonio Bianchi ${ }^{2} \oplus$, Nelson Diehl Kruse ${ }^{1} \oplus$,

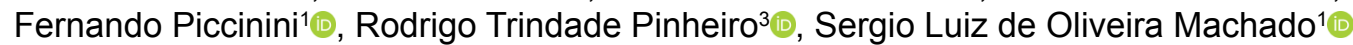

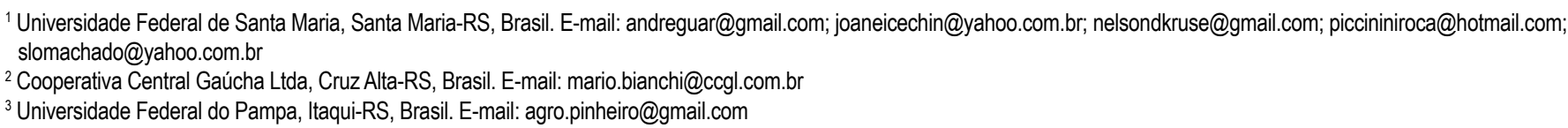

ABSTRACT: Integrated management practices should be recommended to avoid damage of glyphosate-resistant hairy fleabane [Conyza bonariensis (L.) Cronquist] on the soybean. This study aimed to evaluate the effect of soil cover plants and chemical control on the glyphosate-resistant hairy fleabane. Field experiment was performed in a randomized block design, with treatments arranged in a factorial scheme $(3 \times 10)$, using subdivided plots and four replicates. The main factor was composed by three types of soil cover (black oat, wheat and fallow), and on the subplots were evaluated the glyphosate+2,4-D amine in a tank-mix applied at 14 DBS (days before sowing) with sequential application of paraquat+diuron at 01 DBS; burndown performed at 07 DBS using glyphosate alone or applied in a tank-mix with clorimuron-ethyl, diclosulan, imazethapyr, sulfentrazone, and flumioxazine; glyphosate alone applied at the $\mathrm{V}_{4}$ phenological development stage of the soybean, and control without application on Roundup Ready ${ }^{\circledR}$ soybean. The hairy fleabane sensitivity to glyphosate was previously evaluated by the dose-response curve. Hairy fleabane demonstrated low sensibility to glyphosate, with $17,280 \mathrm{~g}$ a.e. ha-1 needed for a $90 \%$ reduction of dry weight. Wheat or black oat reduced the hairy fleabane population density by $95 \%$ and its plants height by $90 \%$ when compared to fallow, allowing the increased herbicide efficacy, regardless of the tank-mix. For the fallow, the tank-mix of glyphosate+2,4-D amine $(1,080+1,340$ $\mathrm{g}$ a.e. $\left.\mathrm{ha}^{-1}\right)$ herbicides with a sequential application of paraquat+diuron $\left(200+100 \mathrm{~g}\right.$ a.i. ha- $\left.{ }^{-1}\right)$ provided a better control level during the evaluated period, protecting the yield potential.

Key words: Conyza spp.; herbicides; management practices; weed

\section{Plantas de cobertura como ferramenta de supressão e incremento para controle de buva}

RESUMO: Práticas de manejo integrado devem ser preconizadas para evitar danos da buva [Conyza bonariensis (L.) Cronquist] resistente ao herbicida glifosato na cultura da soja. $O$ objetivo deste estudo foi avaliar o efeito das plantas de cobertura de solo e o controle químico em buva resistente ao glifosato. $O$ trabalho de campo foi conduzido em delineamento experimental de blocos ao acaso, com tratamentos arranjados em esquema fatorial $(3 \times 10)$, usando parcelas subdivididas e quatro repetições. $\mathrm{O}$ fator principal foram três coberturas do solo (aveia-preta, trigo e pousio) e, nas subparcelas foram avaliados os herbicidas glifosato+2,4-D amina aplicado 14 DAS (dias antes da semeadura) com aplicação sequencial de paraquate+diuron aos 01 DAS; dessecação aos 07 DAS com glifosato isolado ou associado ao 2,4-D amina, clorimuron-etílico, diclosulam, imazetapir, sulfentrazona e flumioxazina; glifosato em estádio $V_{4}$ da soja e testemunha sem aplicação de herbicida em soja Roundup Ready ${ }^{\circledR}$. A sensibilidade da buva ao glifosato foi avaliada previamente através de curva dose-resposta. A buva apresentou baixa sensibilidade ao glifosato com a necessidade de $17.280 \mathrm{~g} \mathrm{e.a.} \mathrm{ha-1} \mathrm{para} \mathrm{redução} \mathrm{de} 90 \%$ da massa seca. A utilização de trigo ou aveia-preta reduziu $95 \%$ a densidade populacional e $90 \%$ a estatura das plantas de buva comparado ao pousio, possibilitando aumento da eficácia dos herbicidas, independente da mistura de tanque. Para o pousio, o uso do herbicida glifosato+2,4-D amina (1080+1340 g e.a. ha-1) seguido da aplicação sequencial de paraquate+diuron (200+100 g i.a. ha-1), proporcionou melhor controle durante todo o período avaliado, protegendo o potencial produtivo.

Palavras-chave: Conyza spp.; herbicidas; práticas de manejo; planta daninha 


\section{Introduction}

Weeds compete with several crops for limiting resources, essential for development, causing economic damage and reduction of the yield potential (Forte et al., 2017). In Brazil, the estimation reports that the weed interference causes losses of more than nine billion Brazilian reals in the soybean crops, taking into account the costs of resistance and yield losses (Adegas et al., 2017).

In the South Region of Brazil, the widespread use of the glyphosate herbicide in soybean and corn Roundup Ready ${ }^{\circledR}$ (RR) cultivated under no-tillage system, combined with the ecological adaptability of the hairy fleabane, favored the selection of populations resistant to the glyphosate herbicide, making the management more difficult and increasing the control costs. Similarly, the selection of glyphosate-resistant hairy fleabane populations also happened in the United States, after intensive use of herbicide in agricultural systems managed under no-tillage. In Brazil, the first evidences on the occurrence of hairy fleabane biotypes [Conyza bonariensis (L.) Cronquist] with resistance to the glyphosate herbicide occurred in 2005, after its repeated use (Lamego \& Vidal, 2008).

After the firstcase emerged, the occurrence of hairyfleabane resistant to glyphosate has increased considerably, with more than 7.7 million hectares infested nowadays (Adegas et al., 2017). The herbicide resistance to 5-enolpyruvylshikimate3-phosphate synthase (EPSPs) inhibitors and management failures due to the herbicides application in advanced stage, combined with the high seed production per plant, easy dispersion, and greater adaptation to the environmental conditions, are all factors that contributed to increase of resistant hairy fleabane cases (Kaspary et al., 2017).

Herbicide-resistant weed populations in several soybean areas do not impede the use of herbicides, but require more attention and changes in the management practices (Wallace et al., 2019). In agricultural systems, cover crops create an unfavorable environment for the germination and development of weeds due to the straw presence on the soil surface, competition for environmental resources and allelopathic effects (Shaner \& Beckie, 2014). For the hairy fleabane, the presence of seeds on the superficial layer in areas cultivated under low disturbance is essential, due to the need for light as a signal to starts the germination process (Vidal et al., 2007).

Management programs with herbicide diversification combined with the use of cultural methods provide a less weed population density, better chemical control and reduction of the resistance evolution (Colbach et al., 2017). Moreover, discontinuous germination flows of the hairy fleabane are frequently found in the field, causing greater control difficulties, increasing the failures and reduced yield. Thus, pre-sowing burndown of soybean with alternative herbicides in areas managed with soil cover plants during the winter period can assist in the efficient control of glyphosate-resistant hairy fleabane and ensure the yield potential. The objective of this study was to evaluate the effect of soil cover plants and chemical control on hairy fleabane resistant to glyphosate.

\section{Materials and Methods}

The field experiment was carried out in an experimental area located in the municipality of Cruz Alta - RS $\left(28^{\circ} 36^{\prime}\right.$ $S$ latitude and $53^{\circ} 40^{\prime} \mathrm{O}$ longitude), in a soil classified as an Oxisol, or typical dystrophic Red Latosol as according to the Brazilian classification (Embrapa, 2013). Previously, the hairy fleabane population sensitivity to glyphosate herbicide was evaluated in a greenhouse, using different dosages of the herbicide. The hairy fleabane population with a history of control failures was collected from the experimental field, in the same area where the field experiment was conducted. After collection, the plants were transplanted into perforated plastic pots ( $1 \mathrm{~L}$ ) containing substrate. The experimental design for the sensitivity study was the randomized blocks, with four replicates. The used doses of the glyphosate herbicide (360 $\mathrm{g} \mathrm{L}^{-1}$ ) were $0.0 ; 67.5 ; 135 ; 270 ; 540 ; 1,080 ; 2,160 ; 4,320$; 8,640 and $17,280 \mathrm{~g}$ a.e. $\mathrm{ha}^{-1}$. The application was performed in plants approximately $15 \mathrm{~cm}$ of height, using a $\mathrm{CO}_{2}$-pressurized backpack sprayer, equipped with a TT 110.015 spray nozzle, spaced at $50 \mathrm{~cm}$, calibrated to spray $95 \mathrm{~L} \mathrm{ha}^{-1}$.

The hairy fleabane sensitivity to glyphosate was evaluated by the shoot dry weight, collected 28 days after the herbicide application, dried in an oven until reaching constant weight and then weighted on an analytical balance, with the values expressed in g plant $^{-1}$. For normalization distribution purposes, the shoot dry weight data were transformed to $\sqrt{ } x+0.5$. These same values were also adjusted to the log-logistic model (Equation 1), proposed by Seefeldt et al. (1995).

$$
\mathrm{y}=\mathrm{C}+\frac{\mathrm{D}-\mathrm{C}}{1+\exp \left[\mathrm{b}\left(\operatorname{Ln}(\mathrm{x})-\operatorname{Ln}\left(\mathrm{GR}_{50}\right)\right)\right]}
$$

In which: $y$ is the estimated response variable; $C$ is the $y$ value that represents the curve lower limit; $D$ is the maximum value of $y ; \operatorname{Ln}(x)$ is the natural logarithm for each dose; $\operatorname{Ln}\left(G R_{50}\right)$ is the natural logarithm of the dose that causes $50 \%$ of the maximum effect in relation to the control; $b$ is the parameter that indicates the curve slope/declivity around the $G R_{50}$.

After confirmation of the population sensitivity, the field experiment was carried out in a randomized block design, with the treatments arranged in a factorial scheme $(3 \mathrm{x}$ 10), using subdivided plots and four replicates. The main plots were represented by three different soil covers in the autumn-winter period (black oat, wheat and fallow), with the subplots composed of different herbicide treatments applied at the pre-sowing of soybean, in experimental units with area of $22 \mathrm{~m}^{2}$ each. The used herbicides were glyphosate+2,4-D amine $(1,080+1,340 \mathrm{~g}$ a.e. ha-1) applied 14 DBS (days before sowing) with sequential application of paraquat+diuron $\left(200+100\right.$ g a.i. ha $\left.^{-1}\right)$ at 01 DBS; burndown at 07 DBS with glyphosate $\left(1,080 \mathrm{~g}\right.$ a.e. $\left.\mathrm{ha}^{-1}\right)$ alone or associated 
with 2,4-D amine (1,340 a.e. $\left.\mathrm{g} \mathrm{ha}^{-1}\right)$, chlorimuron-ethyl (20 g a.i. ha-1 ${ }^{-1}$, diclosulam (25.2 $\mathrm{g}^{\text {a.i. }} \mathrm{ha}^{-1}$ ), imazetapyr (100 g a.i. ha ${ }^{-1}$ ), sulfentrazone (200 g a.i. ha-1) and flumioxazin (50 g a.i. ha-1 ${ }^{-1}$; control without burndown and with application of glyphosate (1080 g a.e. $\mathrm{ha}^{-1}$ ) in the $\mathrm{V}_{4}$ stage of soybean; control without herbicide.

Prior to the cover crops implantation in winter growing season, weeds in the area were controlled with the herbicide paraquat+diuron $\left(200+100 \mathrm{~g}\right.$ a.i. ha $\left.{ }^{-1}\right)$. Sowing of wheat (Fundacep 52) and black oat (BRS 139) was performed midJune in rows spaced at $17 \mathrm{~cm}$, using 350 and 300 seeds $\mathrm{m}^{-2}$, respectively. In addition, the metsulfurom-methyl was applied at a rate of $1.2 \mathrm{~g}$ a.i. $\mathrm{ha}^{-1}$ in the wheat during tillering $\left(\mathrm{V}_{4}\right.$ stage), whereas for the black oat cultivation there was no application of post-emergent herbicide.

Before the herbicide application at the pre-sowing of soybean, the hairy fleabane population density (plants $\mathrm{m}^{-2}$ ) was evaluated at $0,30,60,90$ and 120 days after sowing (DAS) of the cover crops, with counting performed at a previously demarcated point using a $0.4 \times 1.0 \mathrm{~m}$ sample frame. Also, the hairy fleabane height (in $\mathrm{cm}$ ), in the three soil covers, was obtained from 10 plants taken at random from each subplot, and the dry matter from the remaining shoot of the crops was collected in a sampling area of $0.4 \times 1.0 \mathrm{~m}$ at $120 \mathrm{DAS}$. The samples were subjected to drying in an oven at $60^{\circ} \mathrm{C}$ for $72 \mathrm{~h}$, followed by weighing on an analytical balance.

The sowing of the soybean cultivar Fundacep 53 RR was performed in the second half of November, using 32 plants $\mathrm{m}^{-2}$ spaced $50 \mathrm{~cm}$ between rows. In the crop post-emergence, glyphosate $\left(1,080 \mathrm{~g}\right.$ a.e. $\left.\mathrm{ha}^{-1}\right)$ was applied in all treatments at $\mathrm{V}_{4}$ stage (developed third trifoliate) except for the control without application, following a control practice adopted in Roundu Ready ${ }^{\circledR}$ soybean. The herbicides were applied with a $\mathrm{CO}_{2}$-pressurized backpack sprayer, equipped with TT 110.015 spray nozzles, spaced at $50 \mathrm{~cm}$ and calibrated to spray 95 $\mathrm{L} \mathrm{ha}^{-1}$. Meteorological conditions for each application are described in Table 1.

The visual control evaluation of the herbicide treatments were evaluated at 07, 14, 28 and 56 days after application (DAA) using the percentage control scale, in which the zero score represents no damage while the 100 score refers to the complete death of plants (Frans \& Crowley, 1986). At the study end, the yield soybean (in $\mathrm{kg} \mathrm{ha}^{-1}$ ) was obtained with the harvest of $4 \mathrm{~m}^{2}$ from the experimental unit, followed by threshing and cleaning of the samples, weighing and correction of the grain moisture to $13 \%$.
The data obtained were analyzed for normality (Shapiro-Wilk test) and subsequently subjected to analysis of variance ( $p \leq 0.05$ ). In case of statistical significance, the means comparison was performed by the Tukey test ( $p \leq$ 0.05).

\section{Results and Discussion}

The shoot dry weight of the hairy fleabane in the doseresponse curve experiment showed low population sensitivity to glyphosate, with the need of $17,280 \mathrm{~g}$ and ha-1 to reduce the dry weight $\left(G_{90}\right)$ by $90 \%$, equivalent to 24 fold the label recommended rate (Figure 1 ). Similar results regarding the resistance level were obtained in C. canadensis (L.) Cronquist, requiring glyphosate doses greater than $14,000 \mathrm{~g}$ a.e. ha-1 to reduce $82 \%$ of the dry weight (Vangessel et al., 2009). The increased controlling dose required makes the management more difficult and also requires changes in the control strategies, aiming to protect crops from the damage caused by weeds.

Regarding the field experiment in which the cultural practices effects were evaluated, the hairy fleabane population at 120 days after sowing (DAS) in areas managed with wheat and black oat was 98.6 and $95.3 \%$ lower when compared to the winter fallow, respectively (Figure 2), demonstrating its importance in the cold season in the South Region of Brazil. Evaluating the amount of remaining straw

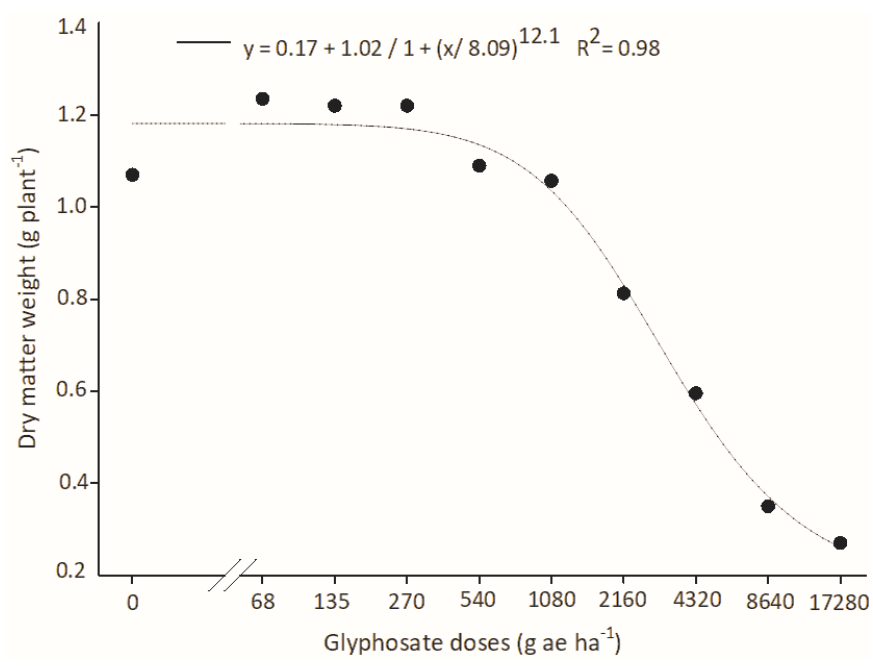

Figure 1. Hairy fleabane dose-response curve in function of different doses of the glyphosate herbicide. Cruz Alta - RS, 2020.

Table 1. Weather conditions found at each herbicide application for hairy fleabane management at the pre-sowing of soybean sowed under different cover plants. Cruz Alta - RS, 2020.

\begin{tabular}{|c|c|c|c|}
\hline Application ${ }^{1}$ & $\begin{array}{c}\text { Temperature } \\
\left({ }^{\circ} \mathrm{C}\right)\end{array}$ & $\begin{array}{c}\text { Air humidity } \\
(\%)\end{array}$ & $\begin{array}{c}\text { Wind speed } \\
\left(\mathrm{km} \mathrm{ha}^{-1}\right)\end{array}$ \\
\hline First application at 14 DBS & 20 & 82 & 7.1 \\
\hline Second application at 07 DBS & 18 & 80 & 9.5 \\
\hline Fourth application at $V_{4}$ stage & 26 & 67 & 6.1 \\
\hline
\end{tabular}

${ }^{1}$ Average conditions found during the herbicides application. 


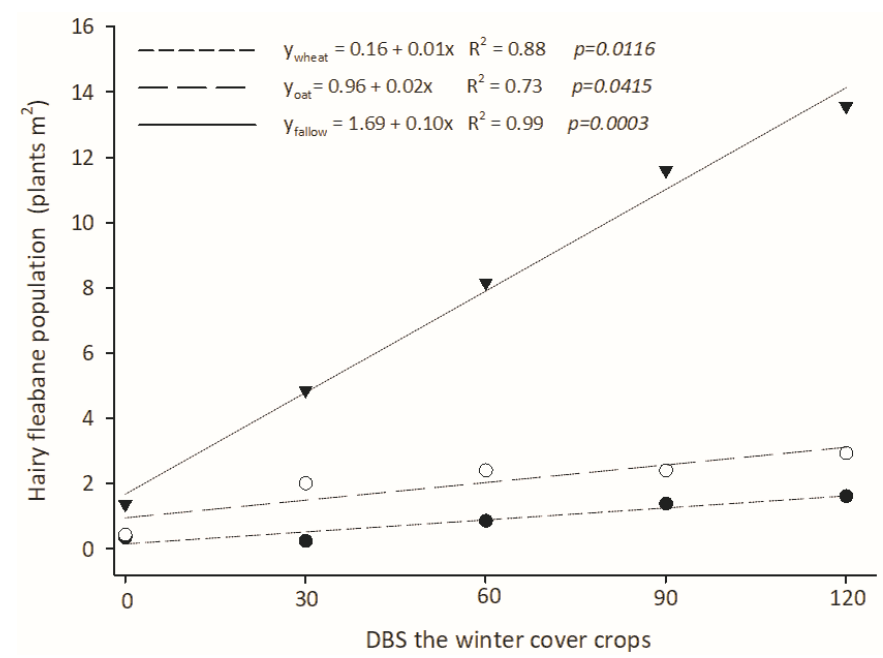

Figure 2. Hairy fleabane population in function of the black oat and wheat covers in comparison with the winter fallow burndown at the pre-sowing of soybean. Cruz Alta - RS, 2020.

from the covers prior to the soybean sowing, the dry weight values were 4.5 and 7.6 tons per hectare for wheat and black oat, respectively.

The consortium of ground cover plants in the cold season allows the production of high amounts of straw, reducing the weed infestation (Cholette et al., 2018). For hairy fleabane, its need for light to start the seeds germination reinforces the importance of cover crops, with an exponential density decrease due to presence of straw on the soil surface (Vidal et al., 2007). Another important factor is the low weight of the seed and the reduced reserves amount, favoring the physical and allelopathic effects of the mulch on the survival of seedlings and seeds. These characteristics were observed in an experiment with $C$. bonariensis seeds in the soil seed bank managed under no-tillage system, with a $6 \%$ monthly viability reduction for seeds allocated up to $2 \mathrm{~cm}$ due to greater microbial activity and predation (Vargas et al., 2018).

Positive effects of the soil cover managed with wheat and black oat were evidenced in the reduction of the population and height of hairy fleabane plants, in comparison with the fallow, with average height at the pre-sowing of soybean less than $5.0 \mathrm{~cm}$, when in the presence of the suppression crops, and above $32 \mathrm{~cm}$ in the winter fallow (Figure 3).

The height reduction of the hairy fleabane plants in areas managed with cover crops favors the chemical control of susceptible and resistant populations when compared to the fallow, since many plants can show a greater development and reduce the herbicides effectiveness (Walker et al., 2012). Recent research with glyphosate-resistant Conyza canadensis has revealed that control with the saflufenacil herbicide at a rate of $25 \mathrm{~g}$ a.i. ha ${ }^{-1}$ was lower for applications performed on plants larger than $25 \mathrm{~cm}$ (Budd et al., 2017), demonstrating that suppression has an important role in the chemical control. Futhermore, the greater plants presence can positively influence the selection of resistant biotypes due to the reduction in the translocation of the glyphosate

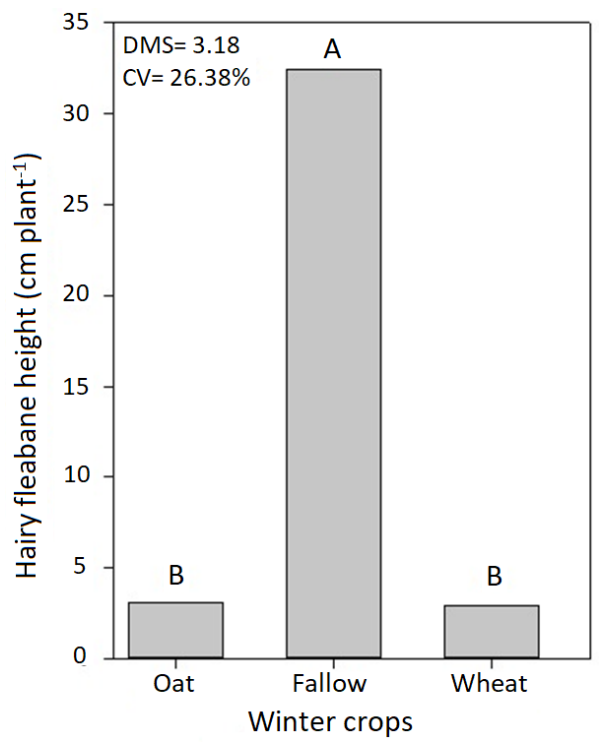

Figure 3. Hairy fleabane height in the different soil usage: winter fallow, black oat and wheat covers in the burndown/ pre-sowing period of soybean. Cruz Alta - RS, 2020. Means followed by the same letter do not differ statistically from each other by the Tukey test $(p<0.05)$. DMS = minimum significant difference; $\mathrm{CV}=$ coefficient of variation.

herbicide and the active ingredient amount that reach the target site of action (Vila-Aiub et al., 2018). Another point regarding the weed suppression as a management practice is the reduction of soil seed bank and lower weed population, a factor that can delay the emergence of new resistance cases, especially when associated with chemical control (Evans et al., 2016).

Hairy fleabane control in burndown in areas managed with Black oat or wheat did not differ statistically between the associations compared to the isolated glyphosate application at the pre-sowing of soybean at 7 and 14 DAA (Table 2).

At 7 DAA, the hairy fleabane control was greater than 95\% for all herbicide treatments used at the pre-sowing, in areas managed with wheat or black oat (Table 2). The herbicides efficiency in winter fallow was lower compared to areas managed with wheat and black oat. For this specific management system, the better result was obtained for the association of glyphosate with 2,4-D, followed by sequential application with paraquat+diuron at 07 DAA. Similarly, the adoption of management practices at the off-season, such as the use of suppressor crops combined with chemical control, was important for the management of glyphosate-resistant palmer amaranth, since the isolated strategies demonstrated low efficiency (Montgomery et al., 2018).

In the evaluation at 14 DAA, the best results were found to the sequential application of paraquat+diuron, with control above $96 \%$ regardless of the autumn management, not differing statistically from the associations of glyphosate with 2,4-D amine, chlorimuron, diclosulam, imazetapyr, sulfentrazone and flumioxazin in areas with black oat or wheat, in which the control was greater than 93\% (Table 
Table 2. Hairy fleabane control (\%) after the herbicide application at the pre-sowing of soybean sowed under different cover plants. Cruz Alta - RS, 2020.

\begin{tabular}{|c|c|c|c|c|}
\hline Herbicides & $\begin{array}{c}\text { Dose } \\
\text { (g a.e. or a.i. ha-1) }\end{array}$ & Black oat & Fallow & Wheat \\
\hline & & & $7 \mathrm{DAA}^{*}$ & \\
\hline Glyphosate+2,4-D/paraquat+diuron & $1,080+1,340 / 200+100$ & $98 \mathrm{aA}$ & $69 \mathrm{bA}$ & 99 aA \\
\hline Glyphosate+2,4-D & $1,080+1,340$ & $98 \mathrm{aA}$ & $70 \mathrm{bA}$ & $98 \mathrm{aA}$ \\
\hline Glyphosate+chlorimuron & $1,080+20$ & 96 aA & $37 \mathrm{bB}$ & $95 \mathrm{aA}$ \\
\hline Glyphosate+diclosulam & $1,080+25.2$ & $95 \mathrm{aA}$ & $34 \mathrm{bB}$ & $96 \mathrm{aA}$ \\
\hline Glyphosate+imazetapir & $1,080+100$ & $97 \mathrm{aA}$ & $38 \mathrm{bB}$ & $96 \mathrm{aA}$ \\
\hline Glyphosate+sulfentrazone & $1,080+250$ & 98 aA & $44 \mathrm{bB}$ & 99 aA \\
\hline Glyphosate+flumioxazin & $1,080+50$ & $98 \mathrm{aA}$ & $43 \mathrm{bB}$ & $98 \mathrm{aA}$ \\
\hline Glyphosate at pre-sowing & 1,080 & 95 aA & $33 \mathrm{bB}$ & $96 \mathrm{aA}$ \\
\hline Glyphosate at post-emergence & 1,080 & $60 \mathrm{aB}$ & $15 \mathrm{bc}$ & $61 \mathrm{aB}$ \\
\hline Control without application & - & $0.0 \mathrm{aC}$ & $0.0 \mathrm{aD}$ & $0.0 \mathrm{aC}$ \\
\hline \multirow[t]{2}{*}{ Coefficient of variation (\%) } & & & 7.2 & \\
\hline & & & $14 \mathrm{DAA}^{*}$ & \\
\hline Glyphosate+2,4-D/paraquat+diuron & $1,080+1,340 / 200+100$ & $99 \mathrm{aA}$ & $96 \mathrm{aA}$ & $99 \mathrm{aA}$ \\
\hline Glyphosate+2,4-D & $1,080+1340$ & 98 aA & $63 \mathrm{bB}$ & $97 \mathrm{aA}$ \\
\hline Glyphosate+chlorimuron & $1,080+20$ & 98 aA & $51 \mathrm{bC}$ & $98 \mathrm{aA}$ \\
\hline Glyphosate+diclosulam & $1,080+25.2$ & $93 \mathrm{bA}$ & $39 \mathrm{bD}$ & 98 aA \\
\hline Glyphosate+imazetapir & $1,080+100$ & 97 aA & $36 \mathrm{bD}$ & 96 aA \\
\hline Glyphosate+sulfentrazone & $1,080+250$ & $95 \mathrm{aA}$ & $36 \mathrm{bD}$ & $98 \mathrm{aA}$ \\
\hline Glyphosate+flumioxazin & $1,080+50$ & $97 \mathrm{aA}$ & $40 \mathrm{bD}$ & $97 \mathrm{aA}$ \\
\hline Glyphosate at pre-sowing & 1,080 & $94 \mathrm{bA}$ & $35 \mathrm{bD}$ & $96 \mathrm{aA}$ \\
\hline Glyphosate at post-emergence & 1,080 & $43 \mathrm{aB}$ & $14 \mathrm{bE}$ & $19 \mathrm{cB}$ \\
\hline Control without application & - & $0.0 \mathrm{aC}$ & $0.0 \mathrm{aF}$ & $0.0 \mathrm{aC}$ \\
\hline Coefficient of variation (\%) & & & 10.3 & \\
\hline
\end{tabular}

"Means followed by the same lowercase (in the row) and uppercase (in the column) letters do not differ statistically from each other by the Tukey test at $5 \%$ of probability.

2). The low control levels obtained for glyphosate-resistant hairy fleabane in the winter fallow occurred due to the higher plant height, in accordance with the previously results. Similar effects have been reported for late application of glyphosate+chlorimuron-ethyl in C. bonariensis, with lower herbicide efficiency (Bressanin et al., 2014). However, the hairy fleabane control through the association of glyphosate with other herbicides with different mechanisms was effective to control of weed resistant, since that performed in a correct stage (Dalazen et al., 2015). This situation has been demonstrated in the control of glyphosate-resistant hairy fleabane associated with the dicamba herbicide, with application evaluated in different development stages, in which the lower control occured to the plants greater than $15 \mathrm{~cm}$, with the need for higher doses in order to obtain high control levels (Hedges et al., 2018).

Similarly, the hairy fleabane chemical control in areas with black oat or wheat was greater in all associations of glyphosate, compared to the winter fallow at 28 DAA, emphasizing the crops importance to suppress the development of hairy fleabane plants (Table 3). In the winter fallow, using glyphosate+2,4-D amine followed by sequential application of paraquat+diuron had the better control level, with $63 \%$ at 28 DAA. For the evaluation at 56 DAA, the application of glyphosate associated with diclosulam, chlorimuron, imazetapy provided the better control levels, with values greater than $93 \%$ in areas managed with black oat or wheat as soil cover (Table 3). A similar result was reported in RR soybean submitted of the application of chloransulam herbicide at a rate of $40 \mathrm{~g}$ a.i. ha ${ }^{-1}$, controlling $91 \%$ of the hairy fleabane, and with chlorimuron at a rate of $20 \mathrm{~g}$ ai ha ${ }^{-1}$ which the control was of $86 \%$ at 42 DAA (Blainski et al., 2015). Additionally, the greater control at 56 DAA in comparison to the previous evaluation (28 DAA), occurred due to the application of glyphosate in the post-emergence in all pre-sowing treatments, except in the control, and following a management practice adopted by farmers in the crops of Roundup Ready soybean.

The application of pre-emergent herbicides within the resistance scenario is important to ensure the crop emergence in areas free from competition. Thus, a recent study showed that the emergence time of weeds has a distinct interference capacity in the soybean, with a critical control period ranging from 14 to 48 days after the crop emergence (Zandoná et al., 2018). On the other hand, cover plants reduced the height plants and promoting a better control efficiency.

For areas managed under winter fallow, the use of glyphosate+2,4-D amine followed by sequential application at the pre-sowing provided the better control levels for weed. Similar results were found in $C$. bonariensis subjected to glyphosate+2,4-D amine application with the sequential of paraquat or diquate, with greater control of plants compared to the alone glyphosate application (Werth et al., 2010). Thus, these results shown the importance of soil cover to increase the weed control.

The results of this study demonstrated that the hairy fleabane control in winter fallow was lower when compared 
Table 3. Hairy fleabane control (\%) after the herbicides application at the pre-sowing of soybean sowed under different cover plants. Cruz Alta-RS, 2020.

\begin{tabular}{|c|c|c|c|c|}
\hline Herbicides $^{1}$ & $\begin{array}{c}\text { Dose } \\
(\mathrm{g} \text { a.e. or a.i. ha-1) }\end{array}$ & Black oat & Fallow & Wheat \\
\hline & & \multicolumn{3}{|c|}{$28 \mathrm{DAA}^{*}$} \\
\hline Glyphosate $+2,4-\mathrm{D} /$ paraquat+diuron & $1,080+1,340 / 200+100$ & $72 \mathrm{aA}$ & $63 \mathrm{aA}$ & $71 \mathrm{aA}$ \\
\hline Glyphosate+2,4-D & $1,080+1,340$ & $75 \mathrm{aA}$ & $59 \mathrm{cB}$ & $63 \mathrm{bB}$ \\
\hline Glyphosate+chlorimuron & $1,080+20$ & $68 \mathrm{aA}$ & $46 \mathrm{bC}$ & $74 \mathrm{aA}$ \\
\hline Glyphosate+diclosulam & $1,080+25.2$ & $74 \mathrm{aA}$ & $50 \mathrm{bB}$ & $74 \mathrm{aA}$ \\
\hline Glyphosate+imazetapir & $1,080+100$ & $71 \mathrm{aA}$ & $20 \mathrm{bD}$ & $74 \mathrm{aA}$ \\
\hline Glyphosate+sulfentrazone & $1,080+250$ & $66 \mathrm{aA}$ & $28 \mathrm{bD}$ & $63 \mathrm{aB}$ \\
\hline Glyphosate+flumioxazine & $1,080+50$ & $60 \mathrm{bB}$ & $26 \mathrm{cD}$ & $75 \mathrm{aA}$ \\
\hline Glyphosate at pre-sowing & 1,080 & $56 \mathrm{aB}$ & $29 \mathrm{bD}$ & $63 \mathrm{aB}$ \\
\hline Glyphosate at post-emergence & 1,080 & $0.0 \mathrm{aC}$ & $0.0 \mathrm{aE}$ & $0.0 \mathrm{aC}$ \\
\hline Control without application & - & $0.0 \mathrm{aC}$ & $0.0 \mathrm{aE}$ & $0.0 \mathrm{aC}$ \\
\hline \multirow[t]{2}{*}{ Coefficient of variation (\%) } & & \multicolumn{3}{|c|}{13.2} \\
\hline & & \multicolumn{3}{|c|}{$56 \mathrm{DAA}^{*}$} \\
\hline Glyphosate+2,4-D/paraquat+diuron & $1,080+1,340 / 200+100$ & $87 \mathrm{aAB}$ & $85 \mathrm{aA}$ & $87 \mathrm{aAB}$ \\
\hline Glyphosate+2,4-D & $1,080+1340$ & 93 aA & $56 \mathrm{cB}$ & $83 \mathrm{bB}$ \\
\hline Glyphosate+chlorimuron & $1,080+20$ & $96 \mathrm{aA}$ & $59 \mathrm{bB}$ & $93 \mathrm{aA}$ \\
\hline Glyphosate+diclosulam & $1,080+25.2$ & 95 aA & $64 \mathrm{bB}$ & 96 aA \\
\hline Glyphosate+imazetapir & $1,080+100$ & 93 aA & $16 \mathrm{bc}$ & $94 \mathrm{aA}$ \\
\hline Glyphosate+sulfentrazone & $1,080+250$ & $92 \mathrm{aAB}$ & $13 \mathrm{bc}$ & $90 \mathrm{aAB}$ \\
\hline Glyphosate+flumioxazine & $1,080+50$ & $78 \mathrm{aC}$ & $22 \mathrm{bC}$ & $83 \mathrm{aB}$ \\
\hline Glyphosate at pre-sowing & 1,080 & $82 \mathrm{aB}$ & $21 \mathrm{bC}$ & $78 \mathrm{aB}$ \\
\hline Glyphosate at post-emergence & 1,080 & $70 \mathrm{aC}$ & $5,0 \mathrm{cD}$ & $46 \mathrm{bC}$ \\
\hline Control without application & - & $0.0 \mathrm{aD}$ & $0.0 \mathrm{aD}$ & $0.0 \mathrm{aD}$ \\
\hline Coefficient of variation (\%) & & \multicolumn{3}{|c|}{11.4} \\
\hline
\end{tabular}

*Means followed by the same letter in the row (lowercase) and in the column (uppercase) do not differ statistically from each other by the Tukey test at the level of $5 \%$ of probability error. ${ }^{1}$ Application of $1,080 \mathrm{~g}$ a.e. ha ${ }^{-1}$ of glyphosate in all treatments, except for the control with no application at $\mathrm{V}_{4}$ stage $( \pm 30 \mathrm{DBS})$.

to the levels obtained in areas managed with black oat or wheat, regardless of the treatment (Figure 4). Furthermore, proactive practices such as the addition of herbicides in a tank-mix with glyphosate, action mechanisms rotation as well as the crop rotation, using cover crops and other management strategies that must be adopted to ensure adequate control of the plants and prevent the emergence of new herbicideresistant populations.

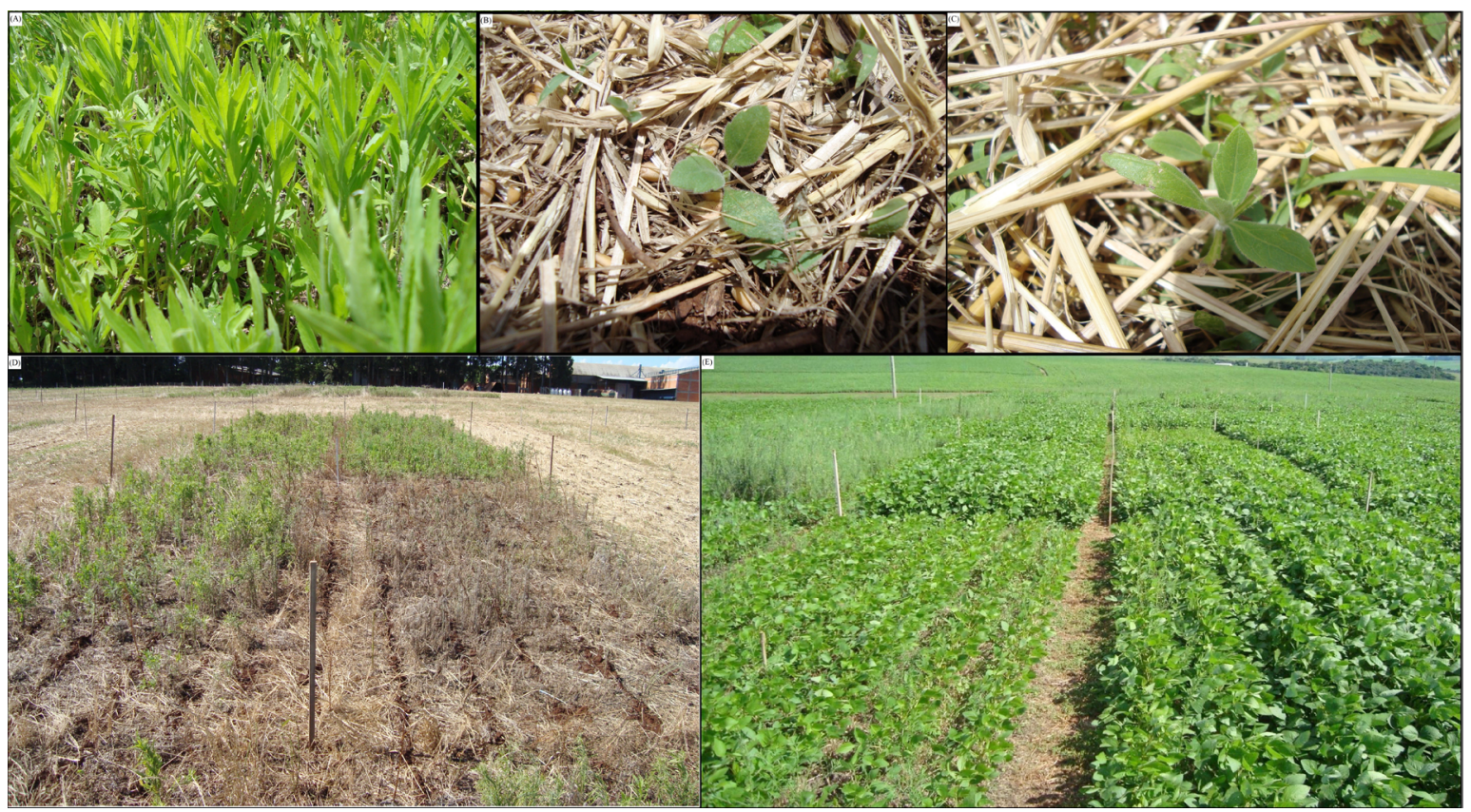

Figure 4. Infestation and height of hairy fleabane resistant to glyphosate at 14 days before the sowing of soybean in the managed areas in winter (A, B and C), fallow area with application of glyphosate+2,4-D amine and sequential of paraquat+diuron at the pre-sowing of soybean (D) and, soybean under hairy fleabane influence after the winter management and chemical control at 40 days after emergence of the crop (E). Cruz Alta - RS, 2020. 
Table 4. Soybean yield $\left(\mathrm{Kg} \mathrm{ha}^{-1}\right)$ after herbicides application at the pre-sowing of soybean sowed under different cover plants. Cruz Alta - RS, 2020.

\begin{tabular}{|c|c|c|c|c|}
\hline \multirow{2}{*}{ Herbicides } & \multirow{2}{*}{$\begin{array}{c}\text { Dose } \\
\left.\text { (g a.e./a.i. ha }{ }^{-1}\right) \\
\end{array}$} & \multicolumn{3}{|c|}{ Grain yield (kg ha-1) } \\
\hline & & Black oat & Fallow & Wheat \\
\hline Glyphosate+2,4-D/paraquat+diuron & $1,080+1,340 / 200+100$ & $3202 \mathrm{aA}$ & $2692 \mathrm{aA}$ & $2924 \mathrm{aA}$ \\
\hline Glyphosate+2,4-D & $1,080+1,340$ & 3051 aA & $2426 \mathrm{aB}$ & 3137 aA \\
\hline Glyphosate+chlorimuron & $1,080+20$ & 3138 aA & $2718 \mathrm{aB}$ & $3284 \mathrm{aA}$ \\
\hline Glyphosate+diclosulam & $1,080+25.2$ & 3029 aA & 2923 aA & 3333 aA \\
\hline Glyphosate+imazetapir & $1,080+100$ & 3065 aA & $2092 \mathrm{aB}$ & $3282 \mathrm{aA}$ \\
\hline Glyphosate+sulfentrazone & $1,080+250$ & 3125 aA & $2226 \mathrm{aB}$ & $3084 \mathrm{aA}$ \\
\hline Glyphosate+flumioxazine & $1,080+50$ & 3046 aA & $2382 \mathrm{aB}$ & 2973 aA \\
\hline Glyphosate at pre-sowing & 1,080 & $3094 \mathrm{aA}$ & $2079 \mathrm{aB}$ & $3236 \mathrm{aA}$ \\
\hline Glyphosate at post-emergence & 1,080 & 2912 aA & 624 bB & $2811 \mathrm{aA}$ \\
\hline Control without application & - & $510 \mathrm{bA}$ & 182 bA & $126 \mathrm{bA}$ \\
\hline Coefficient of variation (\%) & & & 13.35 & \\
\hline
\end{tabular}

For soybean yield, all herbicide treatments used in burndown were superior in comparison to the control and the treatment with glyphosate applied only in the postemergence, under fallow (Table 4). Wheat or black oat as soil cover provided a yield increase from 8 to $27 \%$ in relation to the fallow, depending on the herbicide tank-mix treatment used in the pre-sowing of soybean. For the glyphosate treatment applied in the post-emergence of soybean, the results showed that the grain yield was 4.6 fold higher in areas managed with black oat or wheat, compared to the area without autumn management (Table 4). When evaluating the competition of soybean cultivars with glyphosate-resistant hairy fleabane, yield losses of $25 \%$ were found for areas with infestation of 13 plants $\mathrm{m}^{-2}$ (Trezzi et al., 2013).

For winter fallow areas, soybean yield was higher in the treatments with glyphosate and 2,4-D amine followed by the sequential application of paraquat+diuron and, for the associations of glyphosate with diclosulam and chlorimuron, even though it did not differ statistically from the other tank-mixes recommended at the pre-sowing of soybeans (Table 4). The cultural management with black oat and wheat during the autunn-winter growing season, combined with chemical control with herbicides at the pre-sowing of soybean, favored the management of glyphosate-resistant hairy fleabane, reducing the density and development of the weed population, ensuring better effectiveness of herbicides and higher soybean yield. In the current scenario, where there is a significant increase in cases of resistance to herbicides, integrated management practices are essential for the sustainability of agricultural systems managed under no-tillage reducing the selection pressure and avoid the weed resistance evolution.

\section{Conclusions}

The hairy fleabane population in the studied area had low sensibility to the glyphosate, with $\mathrm{GR}_{90}$ of $17280 \mathrm{~g}$ a.e. ha- ${ }^{-1}$.

Wheat or black oat provides a reduction in the population and the height of hairy fleabane plants, also a greater control level with the glyphosate herbicide and its associations when applied at the pre-sowing of soybean compared to fallow, and greater yield when compared to the control without herbicide application.

In the winter fallow area, the application of glyphosate with 2,4-D amine followed by a sequential of paraquat+diuron, is the most efficient option to control of glyphosate-resistant hairy fleabane, with yield similar to the areas managed with black oat or wheat.

\section{Literature Cited}

Adegas, F.S.; Vargas, L.; Gazzieiro, D.L.P.; Karam, D. Impacto econômico da resistência de plantas daninhas a herbicidas no Brasil. Londrina: Embrapa Soja, 2017. 11p. (Embrapa Soja. Circular técnica, 132). http://ainfo.cnptia.embrapa.br/digital/ bitstream/item/162704/1/CT132-OL.pdf. 02 Ago. 2019.

Blainski, E.; Maciel, C.D.G.; Zobiole, L.H.S.; Rubin, R.S.; Silva, A.A.P.; Karpinski, A.K.; Helvig, E.O. Cloransulam-methyl efficiency in postemergence control of Conyza bonariensis in $\mathrm{RR}^{\mathrm{TM}}$ soybeans crops. Revista Brasileira de Herbicidas, v.14, n.3, p.235-242, 2015. https://doi.org/10.7824/rbh.v14i3.383.

Bressanin, F.N.; Fernieri, A.; Martins, J.F.; Martins, J.V.F.; Alves, P.L.C.A. Controle de biótipos resistentes de Conyza bonariensis com glyphosate + clorimuron-etílico em função do estádio de desenvolvimento. Revista Brasileira de Herbicidas, v.13, n.1, p.68-72, 2014. https://doi.org/10.7824/rbh.v13i1.208.

Budd, C.M.; Soltani, N.; Robinson, D.E.; Hooker, D.C.; Miller, R.T.; Sikkema, P.H. Efficacy of saflufenacil for control of glyphosateresistant horseweed (Conyza canadensis) as affected by height, density, and time of day. Weed Science, v.65, n.2, p.275-284, 2017. https://doi.org/10.1017/wsc.2016.24.

Cholette, T.B.; Soltani, N.; Hooker, D.C.; Robinson, D.E.; Sikkema, P.H. Suppression of glyphosate-resistant Canada fleabane (Conyza canadensis) in corn with cover crops seeded after wheat harvest the previous year. Weed Technology, v.32, n.3, p.244-250, 2018 https://doi.org/10.1017/wet.2018.19.

Colbach, N.; Fernieri, A.; Le Corre, V.; Messéan, A.; Darmency, H. Simulating changes in cropping practises in conventional and glyphosate-tolerant maize. I. Effects on weeds. Environmental Science and Pollution Research, v.24, n.12, p.11582-11600, 2017 https://doi.org/10.1007/s11356-017-8591-7. 
Dalazen, G.; Kruse, N.; Machado, S.; Balbinot, A. Sinergismo na combinação de glifosato e saflufenacil para o controle de buva. Pesquisa Agropecuária Tropical, v.45, n.2, p.249-256, 2015. https://doi.org/10.1590/1983-40632015v4533708.

Empresa Brasileira de Pesquisa Agropecuária - Embrapa. Centro Nacional de Pesquisa de Solos. Sistema brasileiro de classificação de solos. 3.ed. Rio de Janeiro: Embrapa, 2013. 353p.

Evans, J.A.; Tranel, P.J.; Hager, A.G.; Schutte, B.; Wu, C.; Chatham, L.A.; Davis, A.S. Managing the evolution of herbicide resistance. Pest Management Science, v.72, n.1, p.74-80, 2016. https://doi. org/10.1002/ps.4009.

Forte, C.T.; Basso, F.J.M.; Galon, L.; Agazzi, L.R.; Nonemacher, F.; Concenço, G. Habilidade competitiva de cultivares de soja transgênica convivendo com plantas daninhas. Revista Brasileira de Ciências Agrárias, v.12, n.2, 185-193, 2017. https://doi. org/10.5039/agraria.v12i2a5444.

Frans, R.; Crowley, H. Experimental design and techniques for measuring and analyzing plant responses to weed control practices. In: Camper, N. D. (Ed.). Research methods in weed science. 3.ed. Champaign: Southern Weed Science Society, 1986. p.29-45.

Hedges, B.K.; Soltani, N.; Hooker, D.C.; Robinson, D.E.; Sikkema, P.H. Influence of glyphosate/dicamba application rate and timing on the control of glyphosate resistant horseweed in glyphosate/ dicamba resistant soybean. Weed Technology, v.32, n,6, p.678682, 2018. https://doi.org/10.1017/wet.2018.72.

Kaspary, T.E.; Lamego, F.P.; Cutti, L.; Aguiar, A.C.M.; Rigon, C.A.G.; Basso, C.J. Growth, phenology, and seed viability between glyphosate-resistant and glyphosate-susceptible hairy fleabane. Bragantia, v.76, n.1, p.92-101, 2017. https://doi. org/10.1590/1678-4499.542.

Lamego, F.P.; Vidal, R.A. Resistência ao glyphosate em biótipos de Conyza bonariensis e Conyza canadensis no estado do Rio Grande do Sul, Brasil. Planta Daninha, v.26, n.2, p.467-471, 2008. https:// doi.org/10.1590/S0100-83582008000200024.

Montgomery, G.B.; McClure, A.T.; Hayes, R.M.; Walker, F.R.; Senseman, S.A.; Steckel, L.E. Dicamba-tolerant soybean combined cover crop to control palmer amaranth. Weed Technology, v.32, n.2, p.109-115, 2018. https://doi.org/10.1017/wet.2017.96.

Seefeldt, S.S.; Jensen, J.E.; Fuerst, E.P. Log-logistic analysis of herbicide dose-response relationships. Weed Technology, v.9, n.2, p.218225, 1995. https://doi.org/10.1017/S0890037X00023253.
Shaner, D.L.; Beckie, H.J. The future for weed control and technology. Pest Management Science, v.70, n.9, p.1329-1339, 2014. https:// doi.org/10.1002/ps.3706

Trezzi, M.M.; Balbinot JR., A.A.; Benin, G.; Debastiani, F.; Patel, F.; Miotto JR., E. Competitive ability of soybean cultivars with horseweed (Conyza bonariensis). Planta Daninha, v.31, n.3, p.543550, 2013. https://doi.org/10.1590/S0100-83582013000300006.

Vangessel, M.J.; Scott, B.A.; Johnson, Q.R.; White-Hansen, S.E. Influence of glyphosate-resistant horseweed (Conyza canadensis) growth stage on response to glyphosate applications. Weed Technology, v.23, n.1, p.49-53, 2009. https://doi.org/10.1614/ WT-07-108.1.

Vargas, A.A.M.; Agostinetto, D., Zandoná, R.R.; Fraga, D.S.; Avila Neto, R.C. Longevity of horseweed seed bank depending on the burial depth. Planta Daninha, v.36, e0182073, 2018. https://doi. org/10.1590/s0100-83582018360100050.

Vidal, R.A.; Kalsing, A.; Goulart, I.C.G.R.; Lamego, F.P.; Christoffoleti, P.J. Impacto da temperatura, irradiância e profundidade das sementes na emergência e germinação de Conyza bonariensis e Conyza canadensis resistentes ao glyphosate. Planta Daninha, v.25, n.2, p.309-315, 2007. https://doi.org/10.1590/S010083582007000200010 .

Vila-Aiub, M., Casas, C., Gundel, P. E. The role of plant size in the selection of glyphosate resistance in Sorghum halepense. Pest Management Science, v.74, n.5, p.2460-2467, 2018. https://doi. org/10.1002/ps.4923.

Walker, S.; Boucher, L.; Cook, T.; Davidosn, B.; McLean, A.; Widderick, M. Weed age affects chemical control of Conyza bonariensis in fallows. Crop Protection, v.38, n.8, p.15-20, 2012. https://doi. org/10.1016/j.cropro.2012.03.008.

Wallace, J.M.; Curran, W.S.; Mortensen, D.A. Cover crop effects on horseweed (Erigeron canadensis) density and size inequality at the time of herbicide exposure. Weed Science, v.67, n.3, p.327338, 2019. https://doi.org/10.1017/wsc.2019.3.

Werth, J.; Walker, S.; Boucher, L.; Robinson, G. Applying the double knock technique to control Conyza bonariensis. Weed Biology and Management, v.10, n.1, p.1-8, 2010. https://doi.org/10.1111/ j.1445-6664.2010.00360.x.

Zandoná, R.R.; Agostinetto, D.; Silva, B.M.; Ruchel, Q.; Fraga, D.S. Interference periods in soybean crop as affected by emergence times of weeds. v.36, e018169361, 2018. https://doi. org/10.1590/s0100-83582018360100045. 